\title{
Impact of Venture Capital in Strategic Emerging Industries on Enterprise Technological Innovation - Based on GEM
}

\author{
Sun-Lei YANG ${ }^{a}$, Kai-Lun GAO ${ }^{\text {b, }}$, Hui-Yun TANG ${ }^{c}$, Run-Qiu ZHANG ${ }^{d}$ \\ School of Accounting Wuhan Textile University, Wuhan, Hubei, China \\ a50495815@qq.com, ${ }^{\mathrm{b}} 122365710 @ q q . c o m,{ }^{\mathrm{c}} 1226121325 @ q q . c o m,{ }^{\mathrm{d}} 562681715 @ q q . c o m$
}

Keywords: Strategic emerging industries, Technological innovation, Venture capital.

\begin{abstract}
Since its introduction, strategic emerging industries have drawn extensive attention. The relationship between venture capital and technological innovation has also been studied by both domestic and foreign scholars. This article links these three together and conducts an empirical research based on the firm level. The results show that for the enterprises with strategic emerging industries with venture capital background, the more the top ten shareholders, the more the number of venture capital shareholders, the stronger the ability of technological innovation. For enterprises with strategic emerging industries with venture capital background Said that the number of venture capital for the invention of the number of positive impact is not significant but the positive impact on the number of utility models significant.
\end{abstract}

\section{Introduction}

Innovation is the current hot and the focus of innovation process itself is a continuous "burn" process. Therefore, when strategic emerging industries coincide with technological innovation, the high risks and uncertainties in the process may discourage traditional financing such as bank loans. This reality is a constraint on the financing of such enterprises. At the same time, the development of strategic emerging industries is generally characterized by high risks and potential high returns. The characteristics of these strategic emerging industries and the investment preferences that are in line with venture capital investment generally focus on high Technology, high-risk areas. And besides injecting capital, they also participate in the operation of the enterprise. As a result, venture capital is a more suitable means of financing than traditional methods of financing for the development of strategic emerging industries and the realization of technological innovation in industrial enterprises. This paper tries to analyze the data of strategic emerging industries and enterprises in GEM through empirical research and study how the venture capital will have an impact on its technological innovation based on the micro level of enterprises.

\section{Liteature Review and Research Hypothesis}

The research on venture capital initially originated from abroad. Kortum \& Lerner (2000) empirical results show that the venture capital investment, the resulting increase in capital can lead to an increase in the number of patents, and the effect of capital increase on technological innovation is the company's own R \& D investment efficiency of 3.1 times. Shiri and Trabelsi (2010) pointed out that the capital intervention brought by venture capital is conducive to the implementation of high-risk and high-input technological innovation activities, in which the demand of small and emerging enterprises for external venture capital is more obvious. Popov and Boom (2012) argue that when venture capitalists get involved, the question is whether venture capital fosters innovation or whether firms are closer to innovation than finding VCs cash-backed [1]. Many domestic scholars have also conducted research on venture capital in strategic new industries from different angles. Yuan Tian'ang (2010) pointed out that venture capital can better help strategic emerging enterprises to integrate capital, technology and management, and to establish certain restraint mechanisms also play an encouraging role in reducing the moral hazard in the process of financing and inasmuch as information asymmetry The additional costs generated are conducive to the rapid development of strategic emerging industries [2]. Zhang Mingxi (2011) proposed that venture 
capital should be used to guide the idle funds in the capital market to strategic emerging enterprises, especially in the initial stage and the growth stage, and to encourage private capital to invest in strategic emerging industries [3]. However, there are also inconsistent conclusions. Research by Zhao et al. (2013) shows that the intervention of venture capital in the short run can promote the development of strategic emerging industries, but the effect is not obvious in the long run [4]. Zhao Wei and Wen Jun (2015) study the relationship between venture capital and strategic emerging industries and firm performance. The results show that: Generally speaking, the entry of venture capital has a significant inhibitory effect on firm performance only if Venture capital firms, with their high shareholdings and reputable features, can often significantly improve their performance in strategic emerging industries [5]. The innovation of this paper lies in the subdivision of technological innovation, and empirical research on the impact of strategic new-typed industrial venture capital on technological innovation from two aspects of invention and utility model.

After counting the number of VC's among the top ten shareholders who have the background of venture capital, some companies only hold one venture capitalist while others have as many as eight. This article attempts to further study the strategic emerging industries and enterprises that have the background of venture capital investment. For the enterprises with the background of venture capital, whether the more venture capital investment is, the stronger the capability of technological innovation.

Hypothesis 1: Within the strategic emerging industries, the greater the number of venture capital investments among the top ten shareholders, the stronger the technological innovation capability of enterprises

$\mathrm{P}$ patents will be explained in the explanatory variables by using the value of $\mathrm{p}=\mathrm{p} 1+\mathrm{p} 2+\mathrm{p} 3$, while p1, p2 and p3 are decreasing in technological innovation content. The sum analysis does not show the influence of venture capital on their own, An attempt is now being made to analyze whether the separate impact of VCs is consistent or focused on the use of aggregate measures.

Hypothesis 2: In strategic emerging industries, firms with a venture capital background have more 1 inventions than firms without a venture capital background

Hypothesis 3: In emerging strategic industries, firms with venture capital backgrounds have more p2 than firms with no venture capital background

\section{Research Design}

\section{Sources of Data}

The data used in this paper is mainly from the CSMAR GEMS data of Guotai An, selected from 2013-2015. During the statistical analysis, the missing data were excluded and based on the availability and completeness of the data, 169 samples were finally retained. Data processing and analysis, the main use of Excel and stata13 statistical software.

\section{Choice of Variables}

In this paper, the technological innovation of enterprises is the explanatory variable, and the venture capital is the explanatory variable. Because many other factors also affect the performance of technological innovation in enterprises, this paper introduces control variables to control those factors that have a significant impact.

\section{Explained Variable}

Technological innovation is the explanatory variable of this paper, denoted as $p$, which is used to measure the technological innovation capability of the enterprise. The last two hypotheses attempt to analyze the separate effects of venture capital on $\mathrm{p} 1$ and $\mathrm{p} 2$, so the explanatory variables are $\mathrm{p} 1$ and p2. On the measure of technological innovation, this paper chooses the R \& D output, which is the number of patents, to measure the technological innovation capability of enterprises based on the availability of indicators. At present, there are three types of patents in our patent law: invention Pieces, utility model pieces, design pieces. This article records them as p1, p2, p3 in data processing. 
The $\mathrm{p} 1$. Invention refers to a new technical solution to the product, the method or the improvement thereof. p2 utility model refers to the product of the shape, structure or combination of the proposed new practical solutions. p3 design refers to the product's shape, pattern or combination of color and shape, the combination of patterns made of rich aesthetic and suitable for industrial applications of the new design. Technical innovation requirements in descending order. The first two hypotheses in this article will use the sum of these three patent types to measure the number of patents, $\mathrm{p}=\mathrm{p} 1+$ p2 + p3.

\section{Explanatory Variable}

In order to study the impact of venture capital on technological innovation, this paper studies firms with venture capital background, using the number of specific venture capital they have as explanatory variables, denoted by VC number (1-8), to measure the top ten The number of venture capitalists in the stockholders.

\section{Control Variable}

In this paper, the size of the company and the number of years the company as a control variable, because in general, companies will be listed as the longer the life, innovation will also grow with the growth of experience and become stronger. However, after the company is constantly expanding, it will also bring about the corresponding slow pace, ignoring the impact of innovation and other factors that are not conducive to technological innovation. In this paper, the return on assets and Tobin's Q value are taken as the control variables. Because the financial characteristics of the company during the operation of the company will also have a tremendous impact on the company, and technological innovation is no exception. First of all, technological innovation can not be separated without capital itself Second, only financially sound enterprises can develop and progress.

\section{Model Building}

To verify the hypothesis, this paper constructs the following linear regression model

$$
\mathrm{P}=\beta 0+\beta 1 \mathrm{VC}+\beta 2 \text { Size }+\beta 3 \mathrm{ROA}+\beta 4 \text { Tobin } \mathrm{Q}+\beta 5 \text { Age }+\varepsilon
$$

In the above model, P, P1 and P2 are explanatory variables, which respectively represent the number of patents, the number of inventions and the number of utility models. The VC number is an explanatory variable and indicates the number of venture capital investments. The other variables are control variables, Age is the company age, size is the company size, ROA is the return on assets, Tobin Q is the company's market value / asset replacement cost, $\beta 0$ is a constant term, and $\varepsilon$ is the amount of random error.

\section{The Empirical Result Analysis}

\section{Descriptive Analysis}

Table 1: Sample descriptive statistics

\begin{tabular}{|l|l|l|l|l|l|}
\hline Vriable & obs & mean & std.Dev & $\min$ & $\max$ \\
\hline p & 169 & 47.8619 & 51.459 & 1 & 256 \\
\hline VC & 169 & 0.8398 & 0.3679 & 0 & 1 \\
\hline Age & 169 & 1.427 & 0.2254 & 1.0986 & 1.7918 \\
\hline size & 169 & 21.1315 & 0.6268 & 19.5677 & 23.078 \\
\hline ROA & 169 & 0.0466 & 0.04911 & -0.3723 & 0.2446 \\
\hline Tobin Q & 169 & 3.123 & 1.9543 & 0.8464 & 17.8167 \\
\hline
\end{tabular}

First, we make descriptive statistics for the first sample data and get the descriptive statistics of the sample as shown in Table1. We get the four statistical values of sample mean, standard deviation, minimum and maximum, respectively.

The data shows that for the number of patents $(\mathrm{P})$, the difference between the minimum value and 
the maximum value is large, and the standard deviation is 51.4590 , indicating that the number of patents owned by the enterprises varies greatly with a mean of 47.8619, indicating that the average number of patents owned by the enterprises is 47.8619 . For the dummy variable of venture capital number (VC), it is recorded as 1 , not recorded as 0 . For return on assets (ROA), the minimum is negative, but not much different from the maximum. For the company age (Age), the average value of 1.427049, the minimum value of 1.0986, the maximum value of 1.7918 , the standard deviation of 1.4270 , the listing of years of difference is not. For Tobin's Q value, the minimum is 0.8464 , the maximum is 17.8167 , and the average is 3.1230 , which is quite different. For the size of the company, the difference between the minimum value and the maximum value is small, and the standard deviation is 0.6268 , indicating that there is not much difference in the size of the company.

\section{Correlation Analysis}

Table 2 Correlation Analysis of Variables Table (whether there is venture capital background and technological innovation capability)

\begin{tabular}{|l|l|l|l|l|l|l|}
\hline & $\mathrm{p}$ & $\mathrm{VC}$ & size & Age & Tobin Q & ROA \\
\hline $\mathrm{p}$ & 1 & & & & & \\
\hline $\mathrm{VC}$ & 0.0347 & 1 & & & & \\
\hline size & $0.1827^{* *}$ & 0.0314 & 1 & & & \\
\hline Age & $0.1786^{* *}$ & 0.0526 & $0.3065^{* * *}$ & 1 & & \\
\hline Tobin Q & -0.0702 & 0.0949 & $-0.3453^{* * *}$ & -0.1258 & 1 & \\
\hline ROA & -0.0394 & $0.1280^{*}$ & 0.0868 & 0.0525 & $0.3289 * * *$ & 1 \\
\hline$* * * \mathrm{P}<0.01 * * \mathrm{p}<0.05 * \mathrm{p}<0.1$
\end{tabular}

The correlation analysis in Table 2 shows that the risk investment is positively related to technological innovation, but the significance is far greater than $10 \%$, which is not significant. So we can not confirm Hypothesis 1 yet and further research is needed.

\section{Regression Analysis}

Table 3 regression results table (technical innovation and the number of venture capital)

\begin{tabular}{|l|l|l|l|}
\hline Vriable & Technological innovation P & Inventions P1 & Practical new pieces P2 \\
\hline VC number & $4.8639^{*}$ & 0.7994 & $3.9623^{* *}$ \\
\hline ROA & $-208.9807^{*}$ & 13.5448 & $-161.8998^{*}$ \\
\hline Age & 4.6958 & 0.3837 & 4.0975 \\
\hline size & 12.0414 & $5.5796^{* *}$ & $10.4698^{*}$ \\
\hline Tobin Q & 0.0011 & 0.6339 & -0.74898 \\
\hline Constant & -228.6383 & $-111.7788^{* *}$ & -210.3126 \\
\hline Obs & 144 & 144 & 144 \\
\hline R-squared & 0.0715 & 0.0524 & 0.0983 \\
\hline
\end{tabular}

It can be seen from Table 3 that the technological innovation capability is positively correlated with the number of venture capital investments, and the $\mathrm{P}$ value of the model is less than 0.1 and is significant at the level of $10 \%$, indicating that the more the venture capital investment, the better the technological innovation capability of enterprises. This proves that Hypothesis 2 holds: in the strategic emerging industries, the greater the number of venture capital investments in the top ten shareholders of a firm, the stronger the technological innovation capability of enterprises. The number of inventions is positively correlated with the number of venture capital investments, and the $\mathrm{P}$ value of the model is greater than 0.1 , The level is not significant, therefore, hypothesis 2 does not hold. The number of utility models is positively correlated with the number of venture capital, and the $\mathrm{P}$ value of the model is less than 0.1 , which is significant at the level of $10 \%$. Assumption 3 holds that the more the number of venture capital investment, the more the number of utility 
models.

\section{Robustness Test}

We now use the return on equity ROE to replace the return on assets ROA test the above assumptions, come to a consistent conclusion.

\section{Conclusions}

In this paper, the relevant data of Cathay Pacific GEM 2013-2015 is used as a sample to empirically study the impact of venture capital on technological innovation in strategic emerging industries. Through the above regression results, the following conclusions can be drawn: For the enterprises with strategic emerging industries with venture capital background, the more the top ten shareholders have more venture capital investors, the stronger their technological innovation ability. And further find that the positive impact of venture capital on technological innovation does not focus on the invention of higher technical content but on the utility model for enterprises with strategic emerging industries with venture capital background. The results show that for venture capital firms with strategic emerging industries, the top ten shareholders, the more venture capital investors, the more corporate utility models.

\section{References}

[1] Popov, A., Roosenboom, P. .. Venture capital and patented innovation: evidence from Europe [J]. Economic Policy, 2012, 27 (71): 447-482.

[2] Yuan Tian Ang. Capital Market to Support the Development of China's Strategic Emerging Industries [J]. Southwest Finance, 2010 (3): 68-71. (In Chinese)

[3] Zhang Mingxi. Development of venture capital investment to foster strategic emerging industries [J]. China Science and Technology Investment, 2011 (3): 64-66. (In Chinese)

[4] Zhao Yulin, Shi Zhangming, Wang Fang. Cointegration Analysis of Strategic Emerging Industries and Venture Capital Development - An Empirical Analysis of China's High-tech Industry [J] .Science \& Technology Progress and Policy, 2013,30 (13): 53-58. (In Chinese)

[5] Zhao Wei, Wen Jun.Strategic Emerging Industry Venture Capital Holdings Performance [J]. Shanxi University of Finance and Economics, 2015 (1): 48-57(In Chinese) 